\title{
KÜLÖNBÖZŐ ALUMÍNIUM ÖTVÖZETEK ELLENÁLLÁS-PONTHEGESZTETT KÖTÉSEINEK ELEMZÉSE
}

\author{
Németh Alexandra \\ adjunktus, Anyagszerkezettani és Anyagtechnológiai Intézet \\ 3515 Miskolc, Miskolc-Egyetemváros, e-mail: metnak@uni-miskolc.hu \\ Dobosy Ádám \\ adjunktus, Anyagszerkezettani és Anyagtechnológiai Intézet \\ 3515 Miskolc, Miskolc-Egyetemváros, e-mail: metda@uni-miskolc.hu

\section{Török Imre} \\ c. egyetemi tanár, Anyagszerkezettani és Anyagtechnológiai Intézet \\ 3515 Miskolc, Miskolc-Egyetemváros, e-mail: metti@uni-miskolc.hu
}

\begin{abstract}
Absztrakt
Napjaink autóiparában az alumínium ötvözetek alkalmazása növekvö tendenciát mutat. Munkánk során az autóiparban leggyakrabban alkalmazott AA5754-H22, AA6082-T6 és az AA7075 ötvözeteket vizsgáltuk. Jelen ötvözetek alakithatósága az elözetes feldolgozás okán szobahömérsékleten korlátozott, erre ad megoldást egy új gyártástechnológia, az alakitással egybekötött hökezelés (HFQ, solution heat treatment, forming, and in-die quenching). Ez a technológia azonban hatással van az alapanyagok hegeszthetöségére is. Ezért munkánk során ennek a technológiának a hatását vizsgálatuk a különbözö aluminium ötvözetek ponthegesztett kötéseinek tulajdonságaira. Az elkészitett pontkötéseken makroszkópi, nyiró-szakitó és keménységmérési vizsgálatokat végeztünk.
\end{abstract}

Kulcsszavak: alumínium ötvözet, ellenállás ponthegesztés, HFQ, AA6082, AA5754

\begin{abstract}
In the automotive industry there is a growing tendency for the application of high strength aluminium alloys. The aluminium alloys studied in this paper are the AA5754-H22 (AlMg3), AA6082-T6 (AlMgSil) and AA7075 (AlZn5.5MgCu). However, their limited formability properties in room temperature mean obstacle when a complicated shape car body panel is formed. In order to successfully form these sheets into the demanded geometry a new process was developed, the hot forming and in-die quenching (HFQ).

However, this technology also changes the weldability of materials. Therefore, in our work we investigated the effect of using $H F Q$ on the properties of the spot welded joints in different aluminium alloys. The spot welded joints were examined by macro testing, shear tension and hardness tests.
\end{abstract}

Keywords: aluminium alloy, resistance spot welding HFQ, AA6082, AA5754 


\section{Bevezetés}

\subsection{Az alumínium ötvözetek hegeszthetősége}

Az alumínium alkalmazása utóbbi évszázadban folyamatosan növekszik az jármú-, autóiparban is, ahol ezt az anyagot már a legjobb müszaki anyagok közé sorolják [1]. Elterjedésük elsődleges oka kis sürüségük és jó korrózióállóságuk. Napjainkban már a növelt szilárdságú alumínium ötvözetek az acélok versenytársainak is tekinthetők. Az 5xxx, a 6xxx és a 7xxxx ötvözöttségi csoportokba tartozó ötvözetek a leggyakrabban alkalmazottak. A munkánk során vizsgált 5764, 6082 és 7075 anyagminőségeket alkalmazzák többek között a BMW 6, a Ferrari 548 Italia, Jaguar XJ, Range Rover modern, prémium gépkocsik alapanyagaként [2].

A nagyszilárdságú alumínium lemezek számos előnyös tulajdonsága mellett ugyanakkor rendelkeznek néhány olyan alkalmazási korláttal, amelyek gátolják az alacsonyabb árkategóriájú gépkocsiknál való felhasználását. Mivel acél helyettesítése más kisebb tömegủ anyagokkal, mint például az alumínium, a magnézium, stb. költséges lehet és nehezen megvalósítható [3]. Nem csak az alapanyagköltség az akadályozó tényező, de a feldolgozási technológia is számos kihívást foglal magában (mint például a képlékenyalakítás és a kötéstechnológiák). Az alumínium lemezek előzetes feldolgozásuk okán kevésbé alakíthatók szobahőmérsékleten, az alakítási tulajdonságaik jól fejleszthetők [3]. Az alumínium ötvözetek legfontosabb jellemzői, amelyek befolyásolják a hegeszthetőséget a következők $[2,4]$ : a felületi oxidréteg, a gázporozitás jelenléte, a melegrepedés-érzékenység a varratban és a hőhatásövezetben, a leromló mechanikai tulajdonságok (kilágyulás), alacsony elektromos ellenállás, a jó hö- és elektromos-vezetőképesség.

Az autóiparban egyik leggyakrabban alkalmazott hegesztéstechnológia az ellenállás ponthegesztés (resistance spot welding, $R S W$ ). Ezen hegesztéstechnológia legfontosabb előnye a könnyü automatizálhatóság (nagy sebesség és rugalmas alkalmazhatóság) nagysorozat gyártás esetén is. Ezzel a technológiával alumínium nehezen hegeszthetö. Azért, hogy a hegesztés során kompenzáljuk a kis villamos ellenállást és a jó hővezetést, kemény vagy extrakemény munkarendet kell alkalmazni, amely nagy hegesztőáramot és kis hegesztési időt jelent. Az alumínium felületén jelenlévő oxidréteg befolyásolja a hegesztés során keletkező kötés tulajdonságait, ezért hegesztés előtt előzetes felület előkészítő müveletek alkalmazása ajánlott. Habár anyagi valamint technológiai okok miatt az ipari gyakorlatban ezt az előkészítési lépést sok esetben elhagyják.

Az 1. ábra a hegesztési paraméterek hatását mutatja a maximális terhelhetőség függvényében 6082 alumínium ötvözet esetén. A ponthegesztés során fontos mechanikai és metallurgiai változások mennek végbe a pontkötésekben. A biztonság és a minőség szempontjából ezen változások vizsgálata kiemelt jelentőséggel bír, mivel az egész kötés szerkezetét megváltoztatja. A hegesztett kötés tulajdonságait befolyásolja a hegesztési áram és idő, az alkalmazott nyomás és a hegesztési ciklus. A bemutatott eredmények alapján elmondható, hogy a nagy hegesztő áram (24-28 kA) és a viszonylag rövid hegesztési idő(2-5 periódus) alkalmazásával jó terhelhetőség érhető el ezeknél a ponthegesztett kötéseknél $[5,6]$.

Jelent kutatómunka célja alakítással egybekötött hőkezelö eljárások (HFQ, solution heat treatment, forming, and in-die quenching) előnyös tulajdonságainak vizsgálata ponthegesztett kötések esetére. 


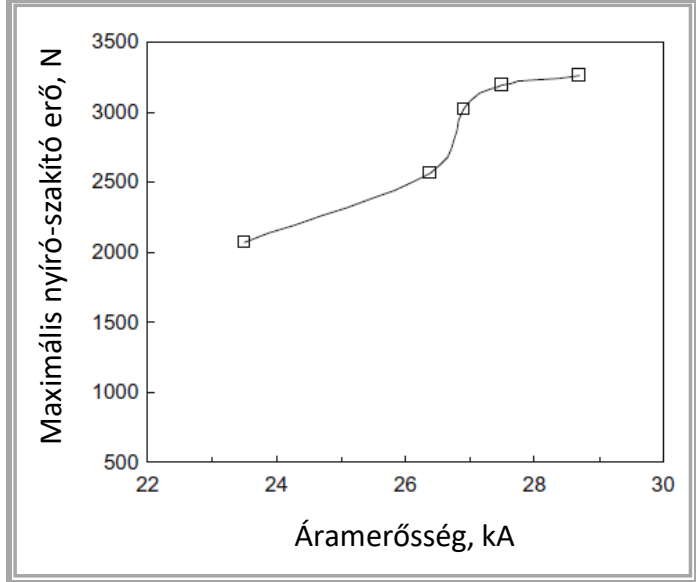

a)

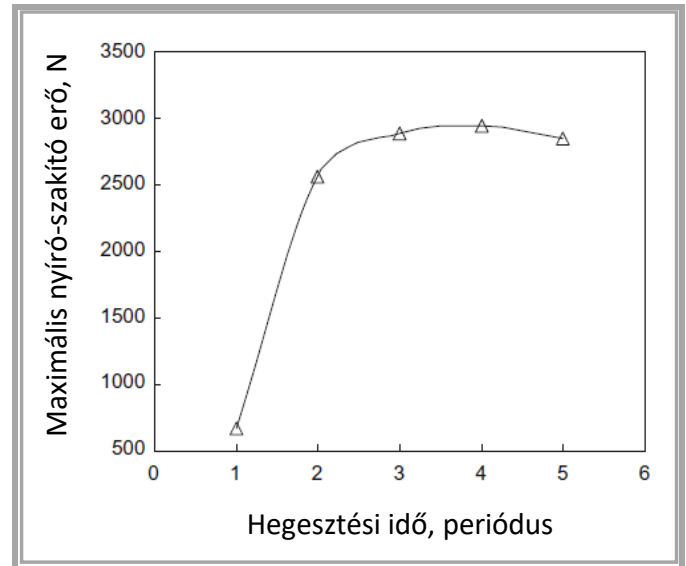

b)

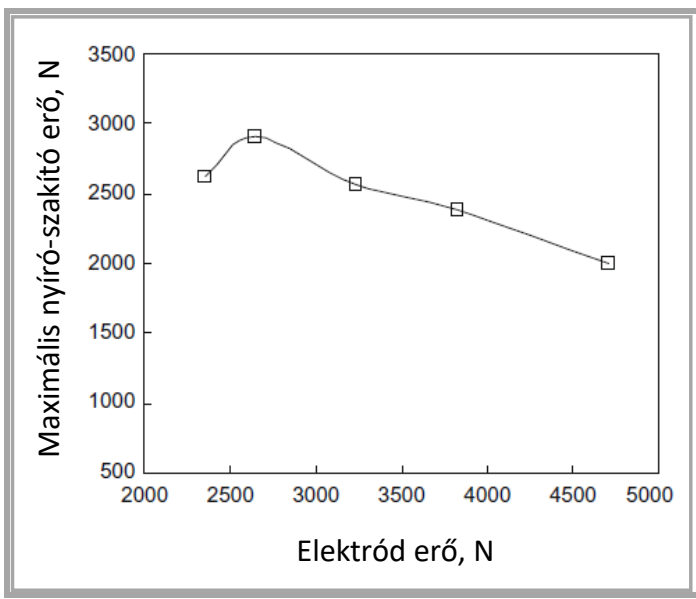

c)

1. ábra. Az áramerösség (a), a hegesztési idö (b) és az elektród erö (c) változásának hatása 6082-T6 anyagminöségü ponthegesztett kötések maximális nyíró-szakitó erejére (lemezvastagság: $1 \mathrm{~mm}$ ) [7] 


\subsection{A HFQ folyamata}

A gépkocsi karosszériák gyártása során az egyik legnagyobb akadály az alumínium ötvözetek nehéz alakításhatósága szobahőmérsékleten, különösen a nagyszilárdságú ötvözeteknél. A HFQ eljárás egy olyan fejlett alakítástechnológia, amely komplex alakzatokat tud létrehozni ezekből az ötvözetekböl. A hegesztés technológiára is közvetetten pozitív hatással lehet a HFQ technológiák alkalmazása [8]. A HFQ folyamat minden esetben, ötvözöttségtől függetlenül, egy magasabb hőmérsékletű oldó izzítással kezdődik, amelynek hatására az alumínium lemezek alakíthatósága javul. Ezt egy rendkívül gyors hütési fázis követi a szobahőmérséklet eléréséig, amelyet a hideg képlékenyalakító szerszámban végeznek el az alakítással egy lépésben. A kötés kialakítása során az alapanyag lágyított állapotban van.

A sikeres alakítási folyamatot követően gépkocsi karosszéria elemeinek egymáshoz való hegesztése következik, majd az alkatrész átesik egy hőkezelö müveleten (paint shop), ami egy mesterséges öregítési folyamatot jelent. Az ötvözet mechanikai tulajdonságai ekkor kedvezőbbek lesznek.

Figyelembe kell azonban venni, hogy a lemezeket elsősorban a karosszéria kevésbé alakított elemeihez erősítik. Maga a mesterséges öregbítési folyamat összekapcsolódik a gépkocsi karosszériájának festésével, ezért előbb a kötéseket kell elkészíteni (pl. ponthegesztés, ragasztás, klincselés, stb.). Így a kötéseket is hőkezelik, ami befolyásolhatja a hegesztett kötés és a hőhatásövezet mechanikai tulajdonságait egyaránt [9]. A folyamatot a 2. ábra foglalja össze.

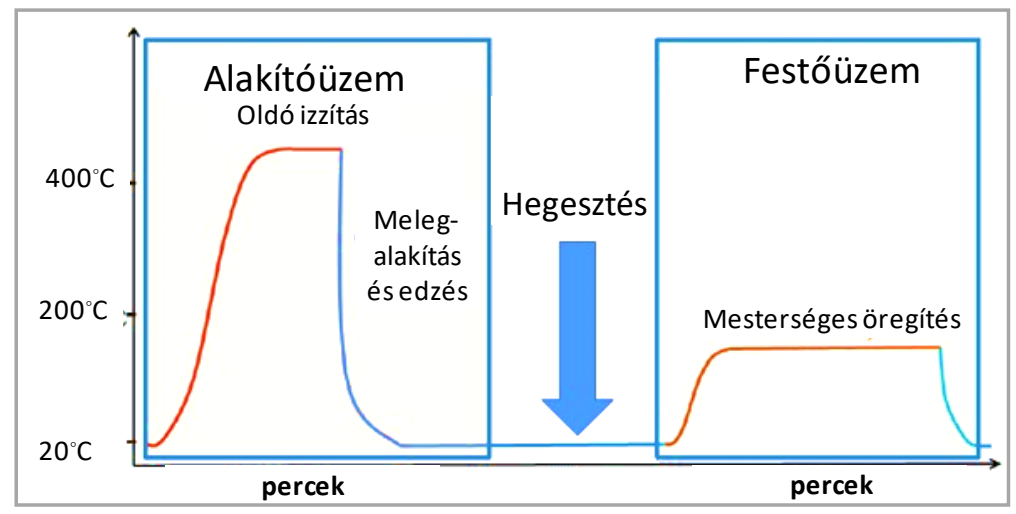

2. ábra. A teljes $H F Q$ folyamat [10]

\section{Gyártási folyamat és vizsgálati módszertan}

A ponthegesztett kötések vizsgálatának egyik célja volt a HFQ technológiai beillesztése a gyártási láncba. Három különböző ötvözetet vizsgáltunk. A HFQ megvalósíthatósága mellett az anyagok hegeszthetőségére gyakorolt hatásának vizsgálata is célja volt munkánknak. Fontos megjegyezni, hogy a HFQ során jelentkező hő hatásával foglalkozunk csak, az alakíthatósággal kapcsolatos megállapításokat nem tettünk.

Az elvégzett vizsgálati program során különböző technológiai „utakat” vizsgáltunk, például: az oldó izzítást követő (solution heat treated, SHT) hegesztést, a mesterségesen öregítés utáni (artifcial aged, $A A$ ) hegesztést, továbbá ennek a kettőnek a kombinációját, vagyis hökezelt állapotban történő hegesztést, majd ezt követő mesterséges öregítést. Vizsgáltuk a hegesztést követő öregítés hatását a hegesztett kötések tulajdonságaira. Ebben az esetben a lemezek kiválásosan keményítve voltak he- 
gesztés elött, ezt követte egy öregítő höciklus. Fontos megjegyezni, hogy az öregítési idő csökkentése egyaránt a kutatómunka céljaihoz tartozott.

Amellett, hogy vizsgáltuk a hegesztés elhelyezését a gyártási láncban, tanulmányoztuk az előzetes felület előkészítő módszerek hatását is. Különböző felület előkészítési módszereket dolgoztunk ki, a hegesztési kísérletek során alkalmaztuk őket és összehasonlítottuk a hegesztett kötések tulajdonságaira gyakorolt hatásukat [11].

\subsection{Vizsgált anyagok}

A leggyakrabban használt alumínium ötvözetekböl három típust választottuk ki: az AA5754-H22, az AA6082-T6 és az AA7075-F anyagokat. A lemezvastagság $1 \mathrm{~mm}$ volt. Az AA5754 alapanyag többnyire magnéziumot tartalmaz, mint ötvözőelemet, szilárdsága alakítással növelt, majd negyedkeménységüre lágyított.

Az AA6082-T6 jelü alapanyag többnyire magnéziumot, szilíciumot tartalmaz és kiválásosan keményítéssel növelik szilárdságát. Ez az ötvözet viszonylag nagy szilárdsággal rendelkezik.

Az 7075-F anyagminőségü ötvözet cinket, magnéziumot és rezet tartalmaz és az egyik legnagyobb szilárdságú ötvözet az általános célú alapanyagok közül. Szakítószilárdsága 500 MPa fölötti. Mindemellett szakadási nyúlása csak 5-11\% közötti, ami korlátozottan teszi alkalmassá gépkocsi karosszériák alapanyagának. Az anyagok összetételét az 1. táblázat tartalmazza, mechanikai tulajdonságaikat a 2. táblázat foglalja össze. A megadott adatok, vagyis a folyáshatár $\left(R_{p 0.2}\right)$, a szakítószilárdság $\left(R_{m}\right)$ és a szakadási nyúlás $\left(\mathrm{A}_{50}\right)$ az 5754-H22 és a 6082-T6 anyagok esetében mübizonylati, míg a 7075-F anyagnál szabványos értékek.

1. táblázat. A vizsgálat alapanyagok kémiai összetétel tömeg\%-ban

\begin{tabular}{|c|c|c|c|c|c|c|c|c|c|}
\hline & $\mathbf{C u}$ & $\mathbf{F e}$ & $\mathbf{M n}$ & $\mathbf{C r}$ & $\mathbf{M g}$ & $\mathbf{T i}$ & $\mathbf{S i}$ & $\mathbf{Z n}$ & $\mathbf{A l}$ \\
\hline $\begin{array}{c}\mathbf{5 7 5 4 -} \\
\mathbf{H 2 2}\end{array}$ & 0,055 & 0,294 & 0,358 & 0,009 & 2,796 & 0,016 & 0,193 & 0,034 & maradék \\
\hline $\begin{array}{c}\mathbf{6 0 8 2}- \\
\text { T6 }\end{array}$ & 0,090 & 0,460 & 0,460 & 0,020 & 0,700 & 0,030 & 0,900 & 0,080 & maradék \\
\hline $\mathbf{7 0 7 5 - F}$ & $1,2-2,0$ & $\leq 0,5$ & $\leq 0,3$ & $0,18-0,28$ & $2,1-2,9$ & $\leq 0,2$ & 0,4 & $5,1-6,1$ & maradék \\
\hline
\end{tabular}

2. táblázat. A vizsgálat alapanyagok mechanikai tulajdonságai

\begin{tabular}{|l|c|c|c|}
\hline & $\mathbf{R}_{\mathbf{p 0 . 2}}, \mathbf{M P a}$ & $\mathbf{R}_{\mathbf{m}}, \mathbf{M P a}$ & $\mathbf{A}_{\mathbf{5 0}}, \boldsymbol{\%}$ \\
\hline $\mathbf{5 7 5 4 - H 2 2}$ & 137 & 220 & 22 \\
\hline $\mathbf{6 0 8 2}-\mathbf{T 6}$ & 303 & 348 & 15 \\
\hline $\mathbf{7 0 7 5 - F}$ & 503 & 572 & 11 \\
\hline
\end{tabular}

\subsection{Vizsgálati körülmények}

Az alumínium lemezekből $100 \times 30 \mathrm{~mm}$ méretủ lemezdarabokat munkáltunk ki. Az átlapolás 30 mm volt, ami megfelelő a nyíró-szakító vizsgálatokhoz. A próbatestek kialakítását a 3. ábra szemléleti. 


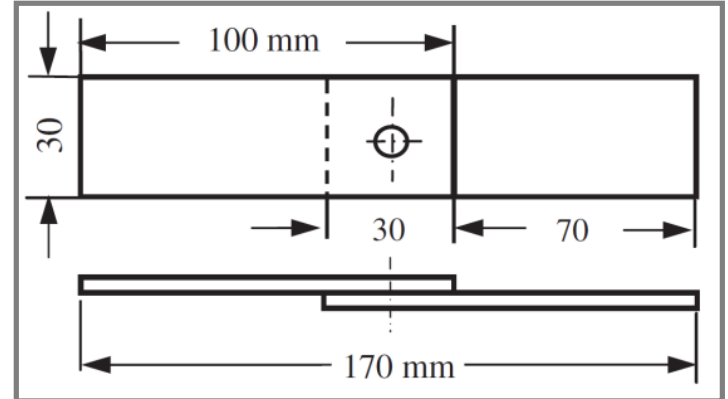

3. ábra. A próbatestek kialakitása nyíró-szakitó vizsgálatokhoz

A hegesztett kötések elkészitéséhez TECNA 8007 típusú hegesztőgépet használtunk TE 550 típusú vezérléssel. A gép állványos, helyhez kötött kivitelü, pont- és dudorhegesztésre alkalmas, programozható, parallel löketü, egyfázisú, váltakozó áramú berendezés, 300 kVA névleges teljesítményhatárral, 30 kA névleges szekunder köri árammal. A hegesztőgép a környezeti terhelés és a kenőanyagok mellőzése miatt pneumatikus hengerrel van ellátva, ahol a megfelelő hütésről vízhütésü rendszer gondoskodik.

A berendezést továbbá egy második szeleppel és nyomásszabályozóval láttuk el, annak érdekében, hogy meg tudjuk valósítani a hegesztés közbeni nyomásnövelést, amellyel megakadályozható a szívódási üregek keletkezése és a melegrepedések kialakulása.

A vizsgálatokhoz $\mathrm{Cu}-\mathrm{Al}_{2} \mathrm{O}_{3}$ kompozit félgömbelektródot használtunk, amely lekerekítési sugara 7,5 $\mathrm{mm}$ volt. Szakirodalmi adatokra, valamint az elvégzett előkísérletekre alapozva meghatároztuk a hegesztés munkatartományát az AA5752-H22 ötvözetre $1 \mathrm{~mm}$ lemezvastagságra és ezeket a paramétereket használtuk a hegesztési kísérletek elvégzése során. A hegesztési munkatartományt az 4. ábra szemlélteti, ahol a zölddel jelölt terület jelöli a hegesztés során ténylegesen használt paraméterkombinációt (kb. $23 \mathrm{kA}$ és 5 periódus). A hegesztés eredménye szempontjából optimális (kék) tartományt határoló két görbéhez tartozó egyenlet $\left(3,5 \mathrm{x} \mathrm{s}^{0,5}\right.$ és $\left.7 \mathrm{x} \mathrm{s}^{0,5}\right)$ esetén az $\mathrm{s}$ a hegesztendő lemezvastagságnak felel meg, az így kapott értékek a hegesztés utáni heglencse még elfogadható átméröjét jelentik mm-ben.

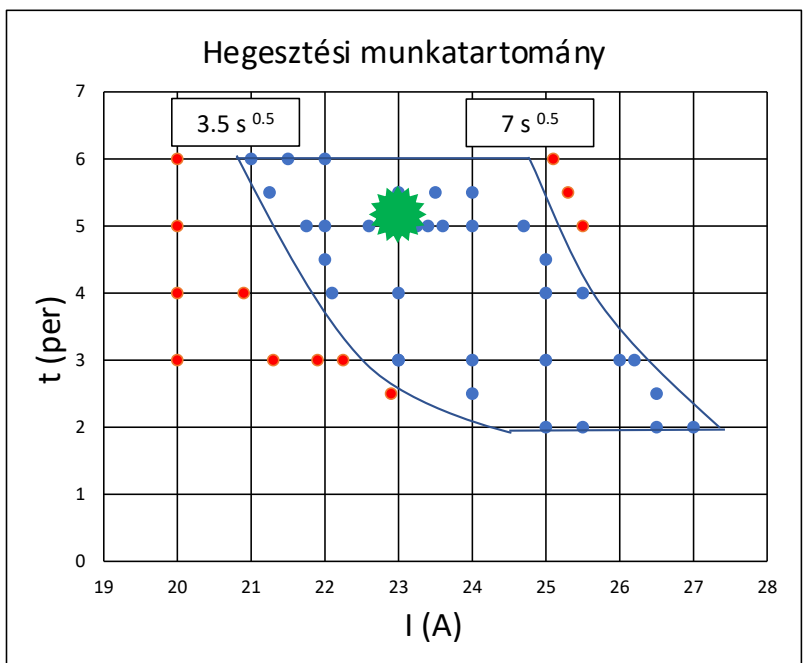

4. ábra. Hegesztési munkatartomány (I: hegesztö áram; t: hegesztési idö; per: periódus) 
A meghatározott munkatartomány és a korábbi kísérletek $[12,13]$ alapján kiválasztottuk az általunk használt hegesztőgépen leadható legnagyobb áramerősséget (kb. $23 \mathrm{kA})$ és két különböző elektród erőt $(2,7 \mathrm{kN} 3$ periódusig és $4,4 \mathrm{kN} 2$ periódusig). Az előszorítási (t) és az utánszorítási időt (t) egy-egy periódusra állítottuk, a hegesztési idő $\left(\mathrm{t}_{\mathrm{h}}\right) 5$ periódus volt. Így egy pontkötés elkészítéséhez szükséges ciklus 7 periódusig tartott. Az alkalmazott gép esetében, $50 \mathrm{~Hz}$-es müködés mellett, 1 periódus $0,02 \mathrm{~s}$ ideig tart. Az alkalmazott teljes hegesztési ciklust az 5. ábra szemléleti.

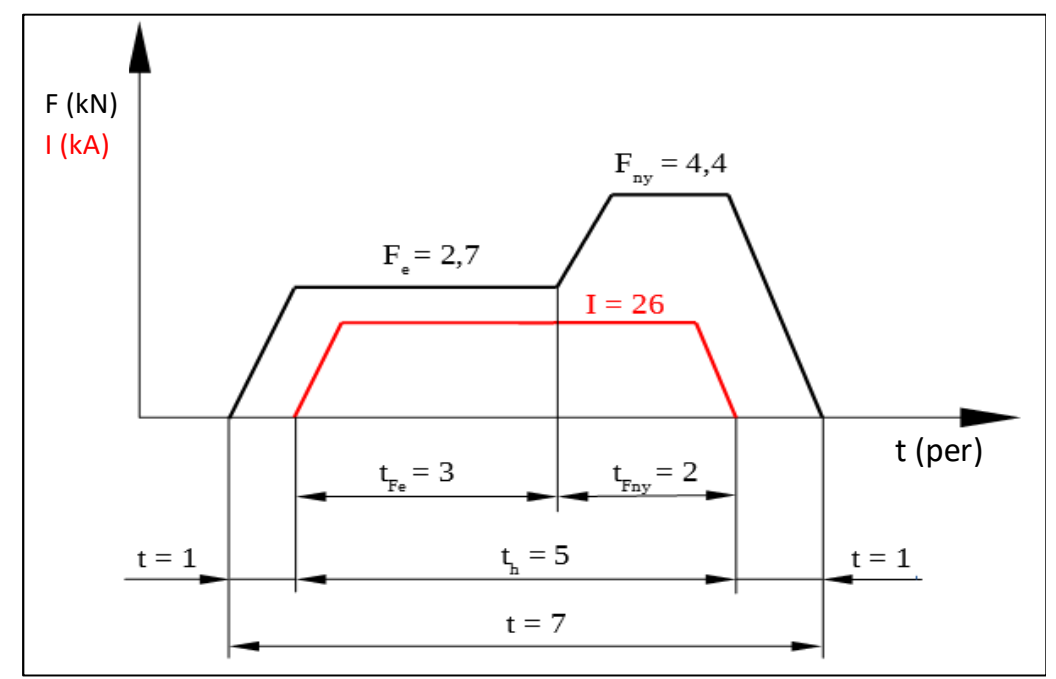

5. ábra. A kötések elkészitéséhez alkalmazott hegesztési ciklus

$\left(F_{e}\right.$ : elöszoritó erö, $k N ; F_{n y}:$ utánszoritó erö, $\left.k N\right)$

\subsection{Vizsgálati terv}

Ahhoz, hogy a HFQ hatását kellőképpen meg tudjuk vizsgálni és az ellenállás ponthegesztés technológiai lépését el tudjuk helyezni a gyártási láncban, vizsgálati mátrix segítségével megterveztük a kísérleteket. A hegesztési munkatartomány és a hegesztési ciklus meghatározásához az AA5754-H22 és az AA6082-T6 alumínium ötvözeteken végeztünk vizsgálatokat az alábbi párosításokkal: $5754+5754,5754+6082$ és $6082+6082$. A lemezek előkészítésekor alkohollal áttöröltük azokat. Az AA6082-T6 és az AA7075-F anyagok esetében meghatározott vizsgálati mátrixot a 3. és 4. táblázat foglalja össze. Annak érdekében, hogy az oxideltávolítás hatását elemezni tudjuk, előzetes felület elökészítési módokat terveztünk, amelyek különböző kémiai maratásokon alapuló [12] eljárásokat jelentenek. Ezeket az 5. táblázat foglalja össze.

Fontos megjegyezni, hogy a hőkezelési paraméterek és a felület előkészítési módok a különböző alapanyagoknál különbözőek voltak.

A 3. táblázatban alkalmazott rövidítések az alábbiakat jelölik: $\mathrm{SHT}_{6}$ : oldó izzítás $\left(535^{\circ} \mathrm{C} \times 2 \mathrm{~min}\right.$ ); $\mathrm{AA}_{6}$ : mesterséges öregítés $\left(190{ }^{\circ} \mathrm{C} \times 9 \mathrm{~h}\right) ; \mathrm{FA}_{6}$ : gyors öregítés $\left(220^{\circ} \mathrm{C} \times 5 \mathrm{~min}, 15 \mathrm{~min}\right.$ hevítéssel), RSW: ellenállás ponthegesztés.

A 4. táblázatban alkalmazott jelölések az alábbiak: $\mathrm{SHT}_{7}$ : oldó izzítás $\left(485^{\circ} \mathrm{C} \times 2 \mathrm{~min}\right)$; $\mathrm{AA}_{7}$ : mesterséges öregítés $\left(120^{\circ} \mathrm{C} \times 24 \mathrm{~h}\right)$; $\mathrm{FA}_{7}$ : gyors öregítés $\left(130{ }^{\circ} \mathrm{C} \times 30 \mathrm{~min}, 15 \mathrm{~min}\right.$ hevítéssel), RWS: ellenállás ponthegesztés. 
3. táblázat. Vizsgálati mátrix az AA6082-T6 ötvözet esetén

\begin{tabular}{|c|c|c|c|c|}
\hline Módszer & \multicolumn{2}{|c|}{ Lépések } & Felület előkészítés \\
\hline $\mathbf{R} 1$ & $\mathrm{SHT}_{6}$ & - & $\mathrm{RSW}$ & $\mathrm{C} 1$ \\
\hline \multirow{2}{*}{$\mathbf{R 2}$} & $\mathrm{SHT}_{6}$ & $\mathrm{AA}_{6}$ & $\mathrm{RSW}$ & $\mathrm{C} 2$ \\
\hline \multirow{2}{*}{$\mathbf{R 3}$} & $\mathrm{SHT}_{6}$ & $\mathrm{RSW}$ & $\mathrm{AA}_{6}$ & $\mathrm{C} 1$ \\
\hline \multirow{2}{*}{$\mathbf{R 4}$} & $\mathrm{SHT}_{6}$ & $\mathrm{FA}_{6}$ & $\mathrm{RSW}$ & $\mathrm{C} 1$ \\
\cline { 5 - 6 } & & & $\mathrm{C} 2$ \\
\hline
\end{tabular}

4. táblázat. Vizsgálati mátrix az AA7075-F ötvözet esetén

\begin{tabular}{|c|c|c|c|c|}
\hline Módszer & \multicolumn{2}{|c|}{ Lépések } & Felület elökészítés \\
\hline $\mathbf{R 5}$ & $\mathrm{SHT}_{7}$ & - & $\mathrm{RSW}$ & $\mathrm{C} 1$ \\
\hline $\mathbf{R} 6$ & $\mathrm{SHT}_{7}$ & $\mathrm{AA}_{7}$ & $\mathrm{RSW}$ & $\mathrm{C} 3$ \\
\hline $\mathbf{R} 7$ & $\mathrm{SHT}_{7}$ & $\mathrm{RSW}$ & $\mathrm{AA}_{7}$ & $\mathrm{C} 1$ \\
\hline R8 & $\mathrm{SHT}_{7}$ & $\mathrm{FA}_{7}$ & $\mathrm{RSW}$ & $\mathrm{C} 3$ \\
\hline
\end{tabular}

5. táblázat. Az AA6082-T6 és az AA7075-F ötvözeteknél alkalmazott tisztitási módszerek

\begin{tabular}{|c|c|c|c|}
\hline Recept & Fürdő összetétele & Fürdő hőmérséklete, ${ }^{\circ} \mathrm{C}$ & Bemerítési idő, $s$ \\
\hline C1 & \multicolumn{3}{|c|}{ Tisztítás: alkohol } \\
\hline $\mathrm{C2}$ & $8 \% \mathrm{HNO}_{3}+2 \% \mathrm{HF}$ & 20 & $30-60$ \\
\hline \multirow{2}{*}{ C3 } & $\begin{array}{l}\text { Elömaratás: } \\
\text { 20g NaOH }\end{array}$ & $80-90$ & 10 \\
\hline & $\begin{array}{c}\text { Maratás: } \\
50 \% \mathrm{HNO}_{3}+2 \% \mathrm{HF}\end{array}$ & 30 & $10-30$ \\
\hline
\end{tabular}

Első lépésként csak alkoholos tisztítást alkalmaztunk. A második módszer szerint, vagyis $\mathrm{C} 2$ receptben feltüntettek alapján, az AA6082-T6 alumínium ötvözet esetén egylépéses módszert alkalmaztunk: $\mathrm{HNO}_{3}$ és HF keverékébe áztattuk, szobahőmérsékleten, 60 másodpercig. A harmadik előkészítési módszer szerint AA7075-F ötvözet esetén kétlépéses felület előkészítési módszert alkalmaztunk, $\mathrm{NaOH}$ oldatos előzetes emelt hömérsékletü $\left(80-90^{\circ} \mathrm{C}\right)$ maratás követően $\mathrm{HNO}_{3}$ és $\mathrm{HF}$ keverékébe merítettük. 


\section{Eredmények és következtetések}

A kötések elkészítését követően makroszkópi vizsgálatokat végeztünk a próbatesteken (1 db), nyíróvizsgálatot $(11 \mathrm{db})$, visszaszórt elektron-diffrakciós elemzést (EBDS, Electron Backscatter Diffraction) (1 db, az AA6082 anyagminőségen) és energiadiszperzív röntgenspektrometriai elemzést (EDS, Energy-dispersive X-ray spectroscopy) (1 db, az AA6082 anyagminőségen).

\subsection{A nyíró-szakító vizsgálatok eredménye}

A nyíró-szakító vizsgálatokat a 3. ábrán látható kialakítású próbatesteken végeztük el. Anyagtakarékossági okok miatt a próbatestek geometriája eltért a szabványos mérettől. A lehetséges károsodási módok a nyíróvizsgálat során a kigombolódás, a részleges kigombolódás és az elnyíródás voltak. A kigombolódás során a hegesztett kötés teljes mértékben kiszakad az alapanyagból (6. ábra) [14].

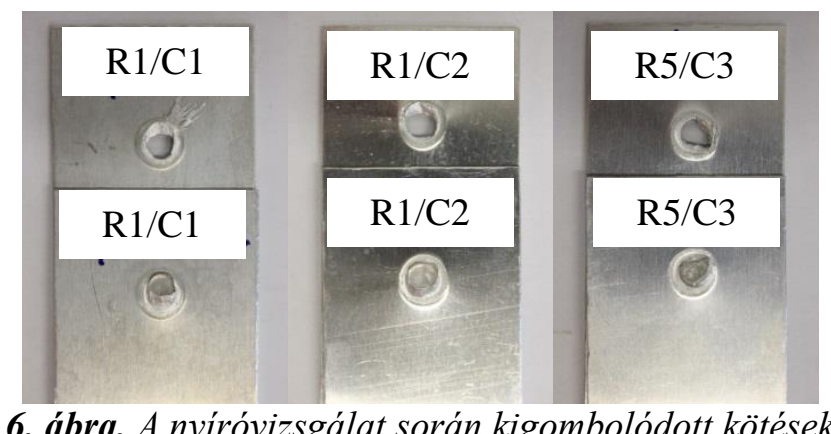

Minden esetben 11 darab próbatesten történt a vizsgálat az EN ISO 15614-12:2017 szabvány szerint meghatározott statisztikai módszer alapján. A maximális nyíró-szakító erő $\left(\mathrm{F}_{\mathrm{Tsi}}, \mathrm{kN}\right)$ és a heglencse átméröje $(\mathrm{d}, \mathrm{mm})$ megmérésre került. Az átlagos nyíró-szakító erő $\left(\mathrm{F}_{\mathrm{Ts}}, \mathrm{kN}\right)$ (1) és a szórás $(\mathrm{SD})$ és a relatív szórás $\left(\mathrm{SD}_{\mathrm{c}}, \%\right)(3)$ került kiszámításra:

$$
\begin{gathered}
\mathrm{F}_{\mathrm{TS}}{ }^{\prime}=\frac{\sum_{\mathrm{i}=1}^{\mathrm{n}} \mathrm{F}_{\mathrm{TSi}}}{\mathrm{n}}, \\
\mathrm{SD}=\sqrt{\frac{\sum_{\mathrm{i}=1}^{\mathrm{n}}\left(\mathrm{F}_{\mathrm{TSi}}-\mathrm{F}_{\mathrm{TS}}\right)^{2}}{\mathrm{n}-1},} \\
\mathrm{SD}_{\mathrm{c}}=\frac{\mathrm{SD}}{\mathrm{F}_{\mathrm{TS}}{ }^{\prime}} \cdot 100,
\end{gathered}
$$

Az előzetes vizsgálatok eredményeit a 6. táblázat foglalja össze, míg a AA6082-T6 és a AA7075-F övözetek eredményeit a 7-8. táblázat tartalmazza.

Az eredményekből tisztán látható, hogy a maratási eljárások alkalmazásával a maximális terhelés 20-30\%-kal nőtt az AA7075-F ötvözet esetében, míg az AA6082-T6 ötvözet esetében nem figyelhető meg szignifikáns eltérés az eredmények között. Az oxideltávolítás további előnye, hogy hegesztés közben kevesebb fröcskölés volt megfigyelhető. Más szempontból, az AA7075-F ötvözet esetében a nyíró-szakító erő magasabb értékeket mutatott, amikor a lemezeken öregítést végeztünk a hegesztést követően. Habár, az öregítés helyének változtatása a technológiai folyamatban nem gyakorolt jelentős 
hatást a szilárdsági eredményekre, ugyanakkor a hegesztést követő öregítésnek előnyösebb eredményeket kellett volna adnia.

6. táblázat. A nyíró-szakitó vizsgálatok elökisérleteinek eredményei $\left(F_{T S i} k N\right)$ különbözö ötvözeteken

\begin{tabular}{|c|c|c|c|}
\hline Próbatest & $\mathbf{5 7 5 4}$ & $\mathbf{5 7 5 4}+\mathbf{6 0 8 2}$ & $\mathbf{6 0 8 2}$ \\
\hline F $_{\text {Ts }}, \mathbf{k N}$ & $\mathbf{2 , 0 4}$ & $\mathbf{2 , 4 4}$ & $\mathbf{2 , 4 0}$ \\
\hline SD & $\mathbf{0 , 2 0}$ & $\mathbf{0 , 2 4}$ & $\mathbf{0 , 1 8}$ \\
\hline SD $_{\mathbf{c}}, \%$ & $\mathbf{9 , 8 5}$ & $\mathbf{9 , 7 3}$ & $\mathbf{7 , 5 8}$ \\
\hline
\end{tabular}

7. táblázat. Az AA6082-T6 ötvözet nyíró-szakitó vizsgálatának eredményei $\left(F_{T S i}, k N\right)$

\begin{tabular}{|c|c|c|c|c|c|c|c|c|}
\hline \multirow{3}{*}{ Próbatest } & \multicolumn{8}{|c|}{ Felület előkészítési és tisztítási módszer } \\
\hline & \multicolumn{2}{|c|}{ R1 } & \multicolumn{2}{|c|}{ R2 } & \multicolumn{2}{|c|}{ R3 } & \multicolumn{2}{|c|}{ R4 } \\
\hline & C1 & $\mathrm{C2}$ & & $\mathrm{C2}$ & C1 & $\mathbf{C 2}$ & $\mathrm{C} 1$ & $\mathrm{C} 2$ \\
\hline & 2,44 & 2,59 & 2,41 & 2,34 & 2,29 & 2,26 & 2,17 & 2,20 \\
\hline & & & & $\mathbf{0 ,}$ & 0,12 & $\mathbf{0 , 2 3}$ & & $\mathbf{0 , 1}$ \\
\hline $\mathrm{SD}_{\mathrm{c}}, \%$ & 4,31 & 3,54 & 3,57 & 3,14 & 5,24 & 10,17 & 4,97 & 7,19 \\
\hline
\end{tabular}

8. táblázat. Az AA7075-F ötvözet nyiró-szakitó vizsgálatának eredményei $\left(F_{T S i}, k N\right)$

\begin{tabular}{|c|c|c|c|c|c|c|c|c|}
\hline \multirow{2}{*}{ Próbatest } & \multicolumn{6}{|c|}{ Felület elökészítési és tisztítási módszer } \\
\cline { 2 - 8 } & \multicolumn{2}{|c|}{ R5 } & \multicolumn{2}{|c|}{ R6 } & \multicolumn{2}{|c|}{ R7 } & \multicolumn{2}{|c|}{ R8 } \\
\cline { 2 - 8 } & C1 & C3 & C1 & C3 & C1 & C3 & C1 & C3 \\
\hline F $_{\text {Ts }}$, kN & 2,14 & 2,57 & 2,37 & 3,27 & 2,70 & 3,25 & 2,66 & 3,49 \\
\hline SD & $\mathbf{0 , 1 2}$ & $\mathbf{0 , 2 3}$ & $\mathbf{0 , 1 3}$ & $\mathbf{0 , 3 6}$ & $\mathbf{0 , 2 2}$ & $\mathbf{0 , 2 4}$ & $\mathbf{0 , 1 3}$ & $\mathbf{0 , 2 6}$ \\
\hline SD $_{\text {c }} \%$ & $\mathbf{5 , 8 4}$ & $\mathbf{8 , 7 5}$ & $\mathbf{5 , 5 2}$ & 11,11 & $\mathbf{8 , 1 5}$ & $\mathbf{7 , 2 2}$ & $\mathbf{5 , 0 3}$ & $\mathbf{7 , 3 3}$ \\
\hline
\end{tabular}

Továbbá megvizsgáltunk egy gyors öregítő eljárást, amelynek célja a gyártási idejének csökkentése a 9, illetve 24 órás mesterséges öregítés lerövidítésével. Az AA6082-T6 ötvözet esetében az eredményeken nem látunk szignifikáns javulást, de az AA7075-F ötvözet esetén jól megfigyelhető a nyírószakító erő növekedése (10-27 \%).

Az elektród kopása ugyancsak befolyásolja a nyíró-szakító vizsgálati eredményeket a hegesztett kötés mértének változása miatt. Ezért fontos a nyíróerő és a heglencse méreteinek összevetésére is.

\subsection{Makroszkópi vizsgálatok}

A makroszkópi vizsgálatokhoz elvágtuk a próbatesteket a középvonalunk mentén. Darabolás, csiszolás, polírozás, valamint maratás után 16x-os nagyításban megvizsgáltuk a hegesztett kötéseket. A kötések deformációinak, kötéshibáinak tanulmányozása mellett, az elkészített felvételeket használtuk a heglencse átmérőjének meghatározására, amely a kötések összehasonlíthatóságának alapját is jelenti egyben. A sztereómikroszkópos képeket a Zeiss Stemi 2000 C digitális kamerával készítettük (7. áb- 
ra). Megállapítottuk, hogy a legtöbb heglencse elvárt alakú volt, nem volt megfigyelhető se repedés, se egyéb hiba sem a varratban, sem a hőhatásövezetben.

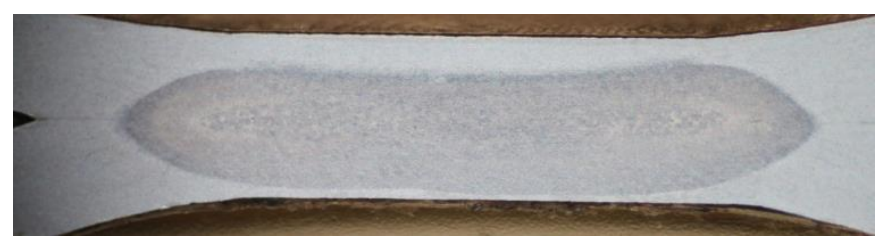

a)

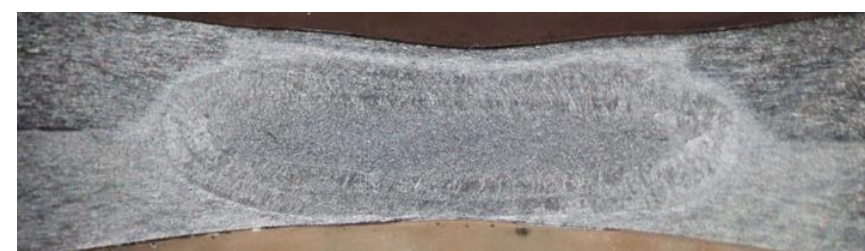

b)

7. ábra. Makroszkópi vizsgálatok a AA6082-T6 (a) és a AA7075-F (b) ponthegesztett kötéseken (Nagyitás: 16x)

\subsection{Keménységvizsgálatok}

Minden esetben végeztünk keménységvizsgálatot is. A terhelőerő $200 \mathrm{~g}$ volt, a lenyomatok közötti távolság $0,2 \mathrm{~mm}$. A mérést az alapanyagban kezdtükés átlós irányban áthaladtunk a heglencsén és az alapanyagban zártuk. Az AA6082-T6 alapanyagi keménysége 90-120 HV0.2, az AA7075-F-ösé 80160 HV0.2 volt hőkezeltségi állapottól függően. A mérésről készített felvételt a 8 . ábra szemlélteti.

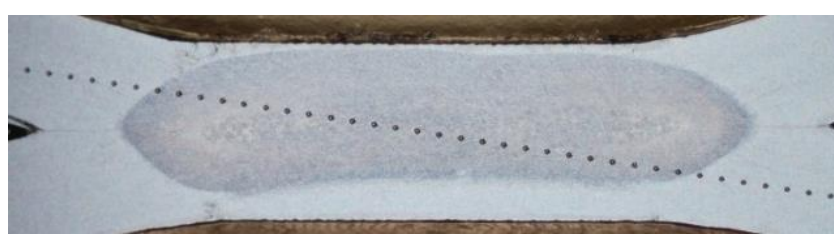

a)

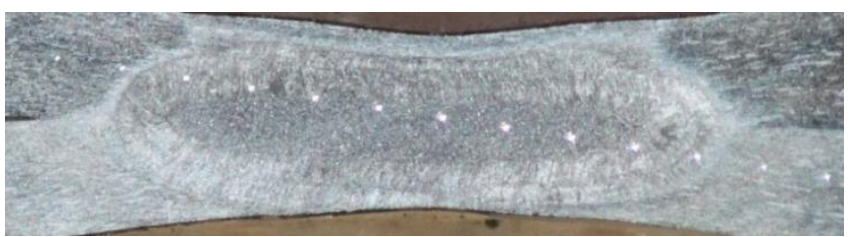

b)

8. ábra. Keménységlenyomatok a höhatásövezetben és a heglencsében az AA6082-T6 (a) és az AA7075-F (b) jelü ponthegesztett kötéseken (Nagyitás 16x)

A mért értékeket a 9. és a 10. ábra foglalja össze. Az ábrák alsó része a keménységlenyomatok elhelyezkedését jelöli a hegesztett kötéseken. Látható, hogy a felület előkészítő módszerek nem befolyásolták a keménységértékeket, így minden esetben egy keménységeloszlást ábrázoltunk. Az ábrák az R1-R8 eredményeket mutatják csak be. 


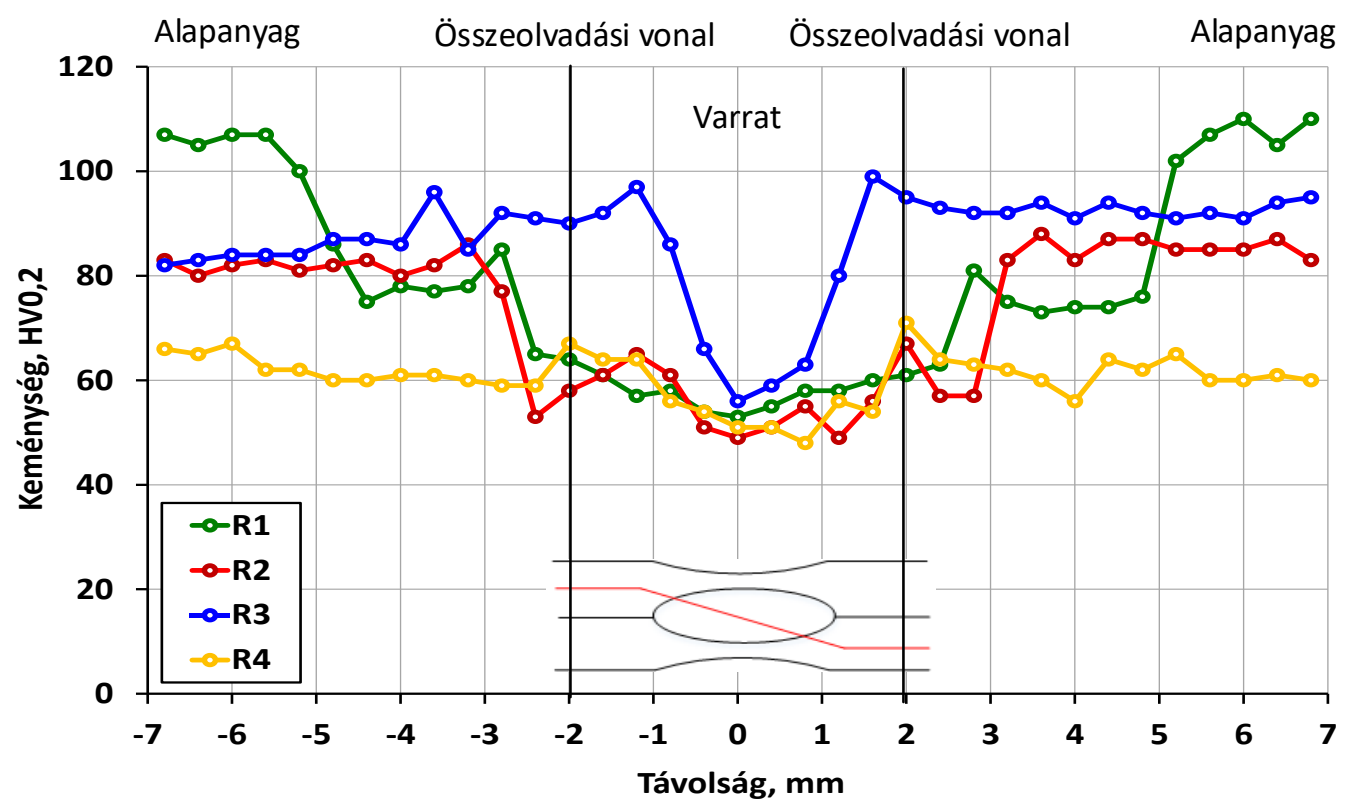

9. ábra. Keménységeloszlás az AA6082-T6 alapanyag hegesztett kötésein

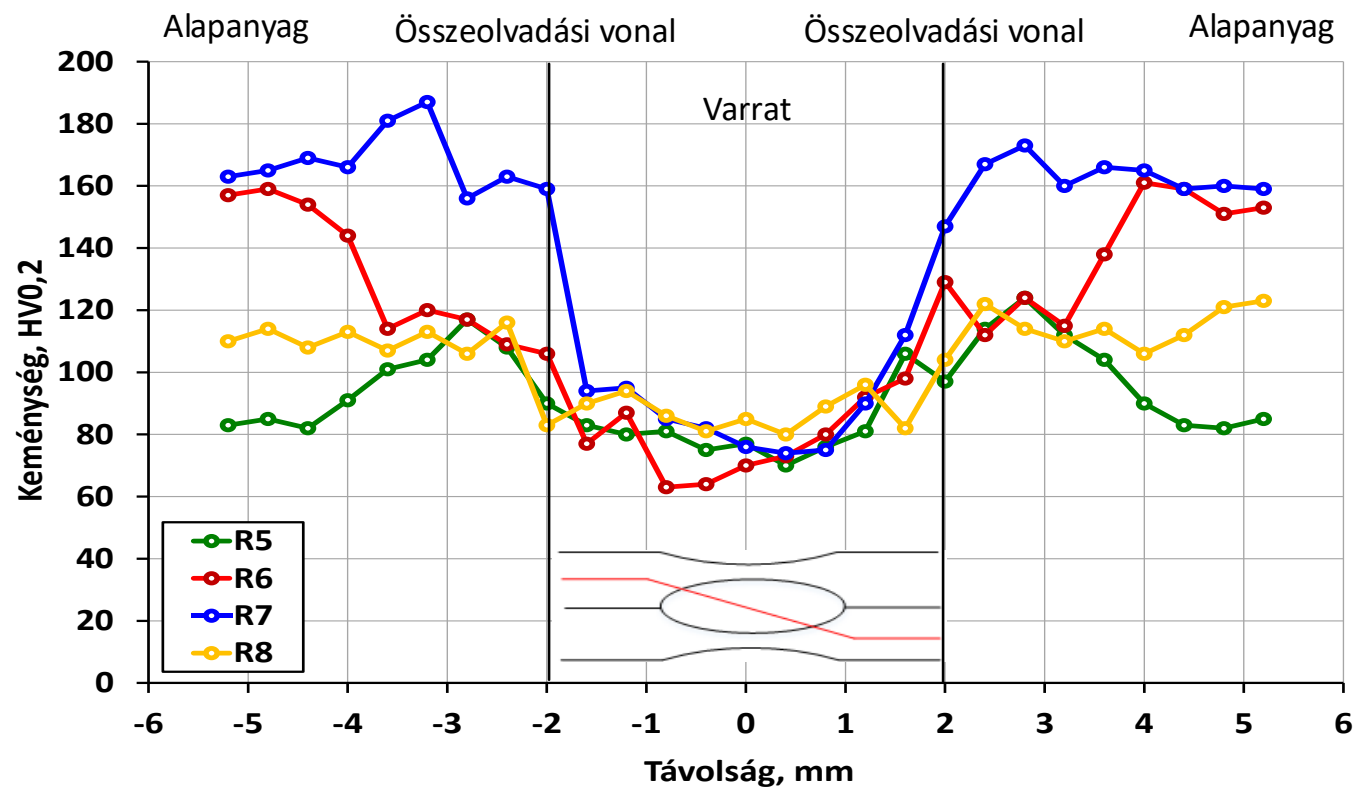

10. ábra. Keménységeloszlás az AA7075-F alapanyag hegesztett kötésein

Fontos kihangsúlyozni, hogy a hökezeltségi állapottól függetlenül minden esetben a höhatásövezetben figyelhettünk meg kilágyulást. A kilágyulás-csökkenés a mikroszkópikus változásoknak és az ötvöző elemek újraoldódásának tudható be.

Az AA6082-T6 ötvözetek esetében szignifikáns kilágyulás volt megfigyelhető a heglencsében és a höhatásövezetben. A keménység 50-60 HV0.2-vel csökkent a heglencsében összehasonlítva az alap- 
anyagban mért 90-120 HV0.2-hez viszonyítva. Továbbá az R3 esetén, mesterséges öregítést követően, kismértékü felkeményedés volt megfigyelhető a höhatásövezetben, a höhatásövezet szélességének csökkenése mellett, ugyanakkor a heglencse keménysége nem változott. A gyors öregítés esetében, mind a hőhatásövezet, mind az alapanyag keménysége szignifikánsan csökkent, ami nem elfogadható.

Az AA7075-F ötvözet esetében a heglencse szignifikáns lágyulása figyelhető meg, amikor is a keménység az alapanyag keménységének felére esett vissza. Ez a jelenség nem kerülhető el, habár a 7075-ös ötvözet keménysége minden esetben nagyobb maradt, mint a 6082-esé. A hagyományos öregítés alkalmazásának előnyős a hegesztett kötések keménységeloszlása szempontjából a 7075-ös ötvözet esetében. Nagyobb keménységértékeket mértünk a hőhatásövezetben a hegesztést követő öregítés esetén (R7). A bemutatott R7-es kezelési terv nagyon hasonló az R3-hoz, ami a legtöbb alumínium ötvözetnél használatos.

\section{4. Összefoglalás}

A ponthegesztett kötések (AA6082-T6 és az AA7075-F alapanyagok, lemezvastagság: 1 mm) vizsgálata során az alábbi következtetések vonhatók le.

- Elmondható, hogy minden egyes kötés minősége megfelelő volt. A vizsgálatokhoz alkalmazott hegesztési paraméterek (kb. $23 \mathrm{kA}$ és 5 periódus) hatékonyan használhatók az autóiparban. A hegesztöáram további növelése és a hegesztési idő további csökkentése ígéretes lehet.

- Az AA6082 és az AA7075 ötvözetek különböző viselkedéssel reagáltak a alakítással egybekötött hőkezelés hatására.

- Az AA6082 ötvözet esetén az alábbi megállapítások tehetők.

- A kémiai tisztítás hatása megfigyelhető volt, azonban a $\mathrm{C} 2$ recept alkalmazása, vagyis $\mathrm{HNO}_{3}$ és HF keverékébe áztatás, szobahőmérsékleten, 60 másodpercig, nem okozott szignifikáns különbséget a kötések teherviselését tekintve, továbbá a fröcskölés mennyiségére sem gyakorolt számottevő hatást.

○ Nem volt megfigyelhető szignifikáns eltérés az azonos paraméterrel hegesztett különbözö módon elökészített próbatestek nyíró-szakító vizsgálatainak eredményei között. A kötések leggyakoribb károsodási módja a kigombolódás volt. A heglencse átméröje 3,9-4,6 mm között változott. A gyors öregítés nem eredményezte az eredmények további javulását.

- A heglencse és a hőhatásövezet jelentős kilágyulása figyelhető meg a keménység mérési eredmények alapján. A keménység 50-60 HV0.2-vel lecsökkent a heglencsében, míg az alapanyagban 90-120 HV0.2 maradt. Ugyanakkor felkeményedés figyelhető meg a hőhatásövezetben a hegesztést követő mesterséges öregítés során, de a heglencsében a keménységeloszlás nem változott.

- Az AA7075 ötvözet esetén az alábbi megállapítások tehetők.

○ A kémiai tisztítás hatása jelentős volt, a C3 módszer - kétlépéses felület előkészítés, amely $\mathrm{NaOH}$ oldatos előzetes emelt hőmérsékletü $\left(80-90^{\circ} \mathrm{C}\right)$ maratás követően $\mathrm{HNO}_{3}$ és HF keverékbe merítését jelentette - javított a 7075-ös alapanyagból készített kötések tulajdonságain a nyíró-szakító vizsgálatok eredményeit tekintve: a nyíró-szakító erő minden esetben nagyobb volt 20-37 \%-kal az előzetesen felületkezelt darabok esetén. Az így létrehozott kötések minőségét figyelembe véve az előkészítési lépés bevezetése mindenképpen javasolható, azonban költségelemzés elvégzésére lehet szükség a megnövekedett gyártási idők miatt.

- A hőkezeltségi állapot jelentős hatást gyakorolt a vizsgálati eredményekre, mivel látható, hogy a nyíró-szakító vizsgálatok során nagyobb erőket mértünk azokon a kötéseken, ame- 
lyek a kötés kialakítás előtt (10-27 \%-os javulás) vagy után (25\%-os javulás) mesterségesen öregítve lettek. Habár az öregítés helyének változtatása a technológiai folyamatban nem gyakorolt jelentős hatást a szilárdsági eredményekre. A pontkötések leggyakoribb károsodási módja a kigombolódás. A heglencse átméröje 4,1-4,8 mm között változott.

- A kötésben kilágyulás figyelhető meg, a keménység az alapanyag keménységének felére esett vissza. Ez a kilágyulás nem kerülhető el, habár a 7075-ös alapanyag keménysége (80160 HV0.2) magasabb maradt mint az 6082 ötvözeté (90-120 HV0.2). A kilágyulás mértéke tovább csökkenthető a mikroszerkezet megváltoztatásával és az ötvözők (újra) oldódásával. A hagyományos öregítés alkalmazása elönyös az 7075-ös ötvözet esetében, de a gyors öregítés ebben az esetben sem vezetett eredményre.

A vizsgálatok eredményei alapján elmondható, hogy az alkalmazott hegesztési paraméterek alkalmazásával jó minőségü kötések hozhatók létre mindkét anyagminőségen. Az AA6082 ötvözetnél nem volt megfigyelhető hatása a felületelőkészítésnek és a hőkezeltségi állapotnak, míg a AA7075 esetén mindkét tényező befolyással bírt. A hőhatásövezet kilágyulása azonban semmilyen esetben sem kerülhetö el.

\section{Köszönetnyilvánítás}

A cikkben ismertetett kutató munka az EFOP-3.6.1-16-2016-00011 jelü „Fiatalodó és Megújuló Egyetem - Innovatív Tudásváros - a Miskolci Egyetem intelligens szakosodást szolgáló intézményi fejlesztése" projekt részeként - a Széchenyi 2020 keretében - az Európai Unió támogatásával, az Európai Szociális Alap társfinanszírozásával valósul meg.

\section{Felhasznált irodalom}

[1] Sakurai T 2008 The Latest Trends in Aluminum Alloy Sheets for Automotive Body Panels. Kobelco Technology Review No. 28. 022-028

[2] Balogh A, Lukács J and Török I (editors) 2015 Weldability and the properties of welded joints. Research on automotive steel and aluminium alloys. University of Miskolc. ISBN 978-963-358081-320-220-9.

[3] Tisza M, Lukács Zs, Kovács P Z, Budai D 2017 Journal of Physics - Conference series 896 001-010. https://doi.org/10.1088/1742-6596/896/1/012087

[4] Pósalaky D, Lukács J, Török I.: 2017 Materials Science Forum 885 261-256. https://doi.org/10.4028/www.scientific.net/MSF.885.251

[5] Han L, Thornton M, Shergold M 2010 Materials and Design 31012-020. https://doi.org/10.1016/j.matdes.2009.08.031

[6] Eggers J, Bothfeld R, Jansen T 2016 Lecture notes in mechanical engineering., Vehicle and Automotive Engineering - Proceedings of the JK2016 1 469-481

[7] Pereira A M, Ferreira J M,Loureiro A, Costa J D M, Bártolo P J 2010 Materials and Design 31 2454-2463. https://doi.org/10.1016/j.matdes.2009.11.052

[8] Fakir O E, Wang L, Balint D, Dear J P, Lin J, Dean T A 2014 International Journal of Machine Tools \& Manufacture 87 039-048

[9] Temmar M, Hadji M, Sahraoui T 2011 Materials and Design 32 3532-3536. https://doi.org/10.1016/j.matdes.2011.02.011

[10] Grohmann T 2016 New Development on Sheet Metal Forming. Proceedings International Conferences on "New Developments in Sheet Metal Forming" and "New Developments in 
Hydroforming" 1 085-102

[11] Cotell C M, Sprague J A, Smidt F A (editors) 1994 ASM Handbook, Volume 5: Surface Engineering 784-804, ASM International. https://doi.org/10.31399/asm.hb.v05.9781627081702

[12] Prém L, Bézi Z, Balogh A 2017 Lecture Notes in Mechanical Engineering XIV 407-423. https://doi.org/10.1007/978-3-319-51189-4_36

[13] Lukács J, Kuzsella L, Koncsik Zs, Gáspár M, Meilinger Á 2015 MATERIALS SCIENCE FORUM 812 149-154. https://doi.org/10.4028/www.scientific.net/MSF.812.149

[14] Radakovic D J, Tumuluru M 2012 An Evaluation of the Cross-Tension Test ofResistance Spot Welds in High-StrengthDual-Phase Steels, Welding Journal 91. 008-015. 